\title{
SNAPSHOT OF PHILANTHROPY'S RESPONSE TO THE GULF COAST HURRICANES
}

\section{By Steven Lawrence \\ Director of Research}

February 2006

Among the 26 named storms tracked in 2005, two hurricanes-Katrina and Rita - will be remembered for the unprecedented devastation they inflicted on the Gulf Coast region. Through the destruction and flooding they left in their wake and, in the case of Katrina, the failure of the New Orleans levee system, these storms caused damage that may take many years to repair. Beyond their physical impact, these storms also revealed grave shortcomings in the nation's ability to respond to large-scale emergencies and placed in broad relief the dire impact of persistent poverty and racial inequality in this country.

In response to the 2005 Gulf Coast hurricanes, foundations, corporations, and other institutional donors have once again provided substantial funding for short-term relief and recovery and made commitments to support long-term rebuilding efforts. Following the model established in tracking the institutional response to the September 11, 2001, terrorist attacks, the Foundation Center has also made a commitment to tracking foundation and corporate giving in response to the Gulf Coast hurricanes over the next several years. As the Center continues to collect and refine its data on donors and recipients, this preliminary documentation of the institutional response will be followed by more extensive and detailed analyses of giving in late 2006 and 2007. We wish to thank the Annie E. Casey Foundation for their generous support of the Foundation Center's Gulf Coast Hurricanes Philanthropic Response Project.
Foundation and Corporate Gulf Coast Hurricane Response Funding as a Share of All Private Giving

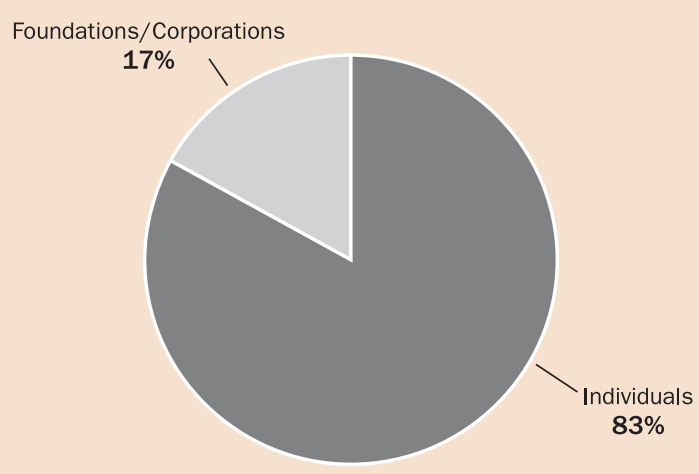

All Private Hurricane Giving $=\$ 2.96$ billion $^{1}$

Source: The Foundation Center, Snapshot of Philanthropy's Response to the Gulf Coast Hurricanes, February 2006. Foundation and corporate figures based on giving announced through November 18, 2005.

${ }^{1}$ Estimate of total private Hurricane Katrina response funding, including in-kind giving, released by the Center on Philanthropy at Indiana University on December 13,2005 . According to the Foundation Center, $\$ 490.2$ million of this total was provided by corporations and foundations. This figure excludes in-kind giving.

For more information, contact Steven Lawrence, director of research at the Foundation Center at (212) 620-4230 or sal@fdncenter.org. Snapshot of Philanthropy's Response to the Gulf Coast Hurricanes is available at foundationcenter.org. 


\section{Sources of Data}

This preliminary report on the institutional donor response to hurricanes Katrina and Rita is based on information provided by foundation, corporate, and other institutional donors via press releases, Web postings, and other public announcements. As part of our ongoing tracking effort, in 2006 the Center will continue to expand the number of institutional donors tracked, conduct a survey of all institutional donors to obtain more detailed information on their giving, and create a database of all Katrina-related institutional contributions. This database will enable the Center to track institutional giving in greater detail, including by recipient organization location and type and by the primary purpose of and population group served by each award.

Foundation and Corporate Gulf Coast Hurricane Response Funding by Donor Type

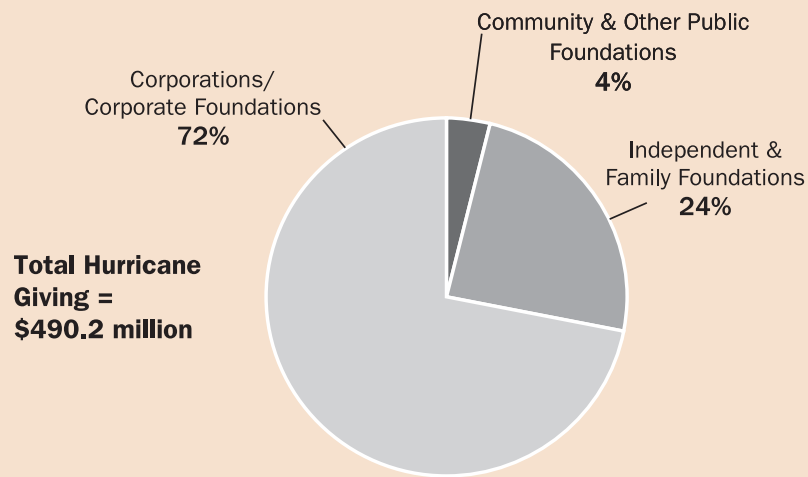

Source: The Foundation Center, Snapshot of Philanthropy's Response to the Gulf Coast Hurricanes, February 2006. Figures based on giving announced through November 18, 2005.
Foundation and Corporate Gulf Coast Hurricane Response Funding by Donor Type*

\begin{tabular}{lrrrr} 
Donor Type & $\begin{array}{c}\text { No. of } \\
\text { Donors }\end{array}$ & \multicolumn{1}{c}{$\%$} & \multicolumn{1}{c}{ Amount } & \multicolumn{1}{c}{$\%$} \\
\hline $\begin{array}{l}\text { Corporations/Corporate } \\
\quad \text { Foundations }\end{array}$ & 260 & 71.6 & $\$ 351,457,948$ & 71.7 \\
$\begin{array}{l}\text { Independent and Family } \\
\quad \text { Foundations }\end{array}$ & 74 & 20.4 & $117,736,129$ & 24.0 \\
$\begin{array}{l}\text { Community Foundations } \\
\text { Other Public Foundations }\end{array}$ & 7 & 1.9 & $5,171,467$ & 1.1 \\
$\quad 22$ & 6.0 & $15,825,000$ & 3.2 \\
$\quad$ TOTAL & $\mathbf{3 6 3}$ & $\mathbf{1 0 0 . 0}$ & $\mathbf{\$ 4 9 0 , 1 9 0 , 5 4 4}$ & $\mathbf{1 0 0 . 0}$
\end{tabular}

Source: The Foundation Center, Snapshot of Philanthropy's Response to the Gulf Coast Hurricanes, February 2006. Figures based on giving announced through November 18, 2005.

Note: Due to rounding, percentages may not total 100.

*Includes cash donations and amounts pledged to match employee gifts; excludes in-kind donations.

Foundation and Corporate Gulf Coast Hurricane Response Funding by Range of Giving*

\begin{tabular}{lrrrr} 
Range of Hurricane Giving & $\begin{array}{r}\text { No. of } \\
\text { Donors }\end{array}$ & \multicolumn{1}{c}{$\%$} & \multicolumn{1}{c}{ Amount } & \multicolumn{1}{c}{$\%$} \\
\hline \$10 million and over & 10 & 2.8 & $\$ 152,100,000$ & 31.0 \\
\$5 million-\$10 million & 19 & 5.2 & $101,000,000$ & 20.6 \\
\$2 million-\$5 million & 29 & 8.0 & $78,170,189$ & 15.9 \\
\$1 million-\$2 million & 117 & 32.2 & $119,630,000$ & 24.4 \\
$\$ 500,000-\$ 1$ million & 38 & 10.5 & $20,356,435$ & 4.2 \\
\$250,000-\$500,000 & 34 & 9.4 & $10,355,000$ & 2.1 \\
$\$ 100,000-\$ 250,000$ & 55 & 15.2 & $6,676,250$ & 1.4 \\
$\$ 50,000-\$ 100,000$ & 22 & 6.1 & $1,232,170$ & 0.3 \\
\$25,000-\$50,000 & 16 & 4.4 & 435,000 & 0.1 \\
Less than $\$ 25,000$ & 23 & 6.3 & 235,000 & 0.0 \\
\multicolumn{1}{c}{ T0TAL } & $\mathbf{3 6 3}$ & $\mathbf{1 0 0 . 0}$ & $\mathbf{\$ 4 9 0 , 1 9 0 , 5 4 4}$ & $\mathbf{1 0 0 . 0}$
\end{tabular}

Source: The Foundation Center, Snapshot of Philanthropy's Response to the Gulf Coast Hurricanes, February 2006. Figures based on giving announced through November 18, 2005

Note: Due to rounding, percentages may not total 100

*Includes cash donations and amounts pledged to match employee gifts; excludes in-kind donations.

Top 15 Corporate Donors Ranked by Total Gulf Coast Hurricane Response Funding*

\begin{tabular}{|c|c|c|c|}
\hline Corporation/Corporate Foundation & State & Amount $^{1}$ & Purpose \\
\hline 1. Starkey Laboratories & MN & $\$ 25,000,000$ & $\begin{array}{l}\text { To support the Starkey Help America Hearing Project, a business recovery program designed to help } \\
\text { with employment, new business plans, and office relocation for hurricane victims }\end{array}$ \\
\hline 2. Wal-Mart & AR & $17,000,000$ & To support the American Red Cross, the Bush-Clinton Katrina Fund, and the Salvation Army \\
\hline 3. Federal Home Loan Bank of Cincinnati & $\mathrm{OH}$ & $15,000,000$ & To establish the Katrina Housing Assistance Fund to aid victims and families \\
\hline 4. Freddie Mac & VA & $10,100,000$ & $\begin{array}{l}\text { To support the American Red Cross, the National Housing Trust Enterprise Preservation Corporation } \\
\text { to provide services to families now living in Dallas and Houston, and the National Center for Missing } \\
\text { and Exploited Children to locate and reunite children missing or displaced from their families }\end{array}$ \\
\hline 5. BP Foundation & IL & $10,000,000$ & To support the American Red Cross in assisting evacuees in Houston and various relief organizations \\
\hline 6. United Health Foundation & MN & $10,000,000$ & To support various relief and recovery organizations \\
\hline 7. Citigroup/Citigroup Foundation & NY & $7,000,000$ & $\begin{array}{l}\text { To support the American Red Cross, Habitat for Humanity, and the National Urban League to provide } \\
\text { assistance to displaced and low-income evacuees with job training, job placement and housing, and } \\
\text { for an employee matching gifts program }\end{array}$ \\
\hline 8. ExxonMobil & TX & $7,000,000$ & To support the American Red Cross Disaster Relief Fund \\
\hline 9. General Electric & CT & $6,000,000$ & To support the American Red Cross \\
\hline 10. BellSouth Foundation & GA & $5,000,000$ & $\begin{array}{l}\text { To support various relief and recovery organizations in providing online virtual courses for students } \\
\text { and online training courses for teachers }\end{array}$ \\
\hline 11. Chevron & $\mathrm{CA}$ & $5,000,000$ & To support the American Red Cross and various relief and recovery organizations \\
\hline 12. Coca-Cola Company & GA & $5,000,000$ & To support the American Red Cross, the Salvation Army, and various relief and recovery organizations \\
\hline 13. Johnson \& Johnson & NJ & $5,000,000$ & To support various relief and recovery organizations \\
\hline 14. Thrivent Financial for Lutherans & MN & $5,000,000$ & To support Habitat for Humanity \\
\hline 15. Verizon Foundation & NY & $5,000,000$ & To support the American Red Cross \\
\hline Top 15 Subtotal & & $\$ 137,100,000$ & \\
\hline All Other Corporate Donors & & $\$ 214,357,948$ & \\
\hline
\end{tabular}

Source: The Foundation Center, Snapshot of Philanthropy's Response to the Gulf Coast Hurricanes, February 2006. Figures based on giving announced through November $18,2005$.

*Includes cash donations and amounts pledged to match employee gifts; excludes in-kind donations. 


\section{THE RESPONSE OF INSTITUTIONAL DONORS}

Institutional donors include corporations and corporate foundations, independent and family foundations, community foundations and other public foundations, and various business and professional associations.

- As of mid-November 2005, the Foundation Center had identified 363 corporations, foundations, and other institutional donors that had together committed $\$ 490.2$ million for relief and recovery efforts in the aftermath of the Gulf Coast hurricanes Katrina and Rita. ${ }^{1}$

- Giving by institutional donors represented over 16 percent of an estimated $\$ 2.96$ billion in total private giving in response to the hurricanes. ${ }^{2}$ This proportion is consistent with the share of overall U.S. private giving accounted for by foundations and corporations. ${ }^{3}$ As additional information on foundation and corporate giving is announced, this share will likely increase.

- Corporations, foundations, and other institutional donors reported a total of 570 commitments. However, the number of individual commitments will rise dramatically as more detailed information on undesignated pledges becomes available. Among the largest awards announced was the Lilly Endowment's \$30 million commitment to the American Red Cross, Salvation Army, and United Way of America, Starkey Laboratories' \$25 million commitment to the Starkey Help America Hear Project, Wal-Mart's \$17 million commitment to the Salvation Army, and the W.K. Kellogg Foundation's $\$ 15$ million commitment to support various relief efforts.
Foundation vs. Corporate Gulf Coast Hurricane Response Funding by Range of Giving
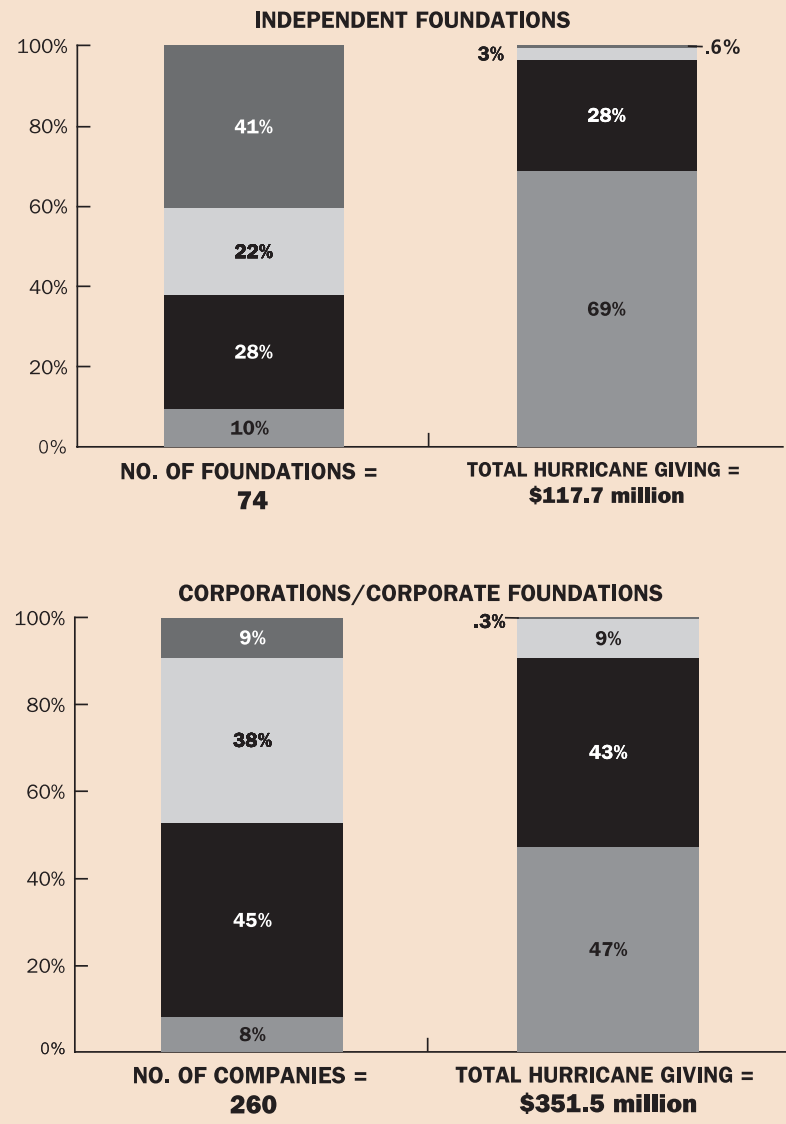

RANGE OF GIVING

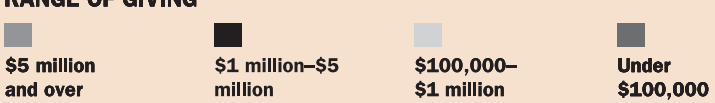

Source: The Foundation Center, Snapshot of Philanthropy's Response to the Gulf Coast Hurricanes, February 2006. Figures based on giving announced through November 18,2005

Top Ten Independent Foundations Ranked by Total Gulf Coast Hurricane Response Funding*

\begin{tabular}{|c|c|c|c|}
\hline Foundation & State & Amount $^{1}$ & Purpose \\
\hline 1. Lilly Endowment & IN & $\$ 30,000,000$ & To support the American Red Cross, the Salvation Army, and the United Way of America \\
\hline 2. W.K. Kellogg Foundation & Ml & $15,000,000$ & To support immediate relief and recovery and long-term rebuilding efforts \\
\hline 3. Ford Foundation & NY & $12,000,000$ & $\begin{array}{l}\text { To assist current grantees and other key organizations in the Gulf Coast states in resuming operations } \\
\text { and meeting the needs of their communities; and to support economic and community development, } \\
\text { leadership development, and the expansion and strengthening of the philanthropic sector in the region }\end{array}$ \\
\hline 4. Andrew W. Mellon Foundation & NY & $10,000,000$ & $\begin{array}{l}\text { To support the Associated College of the South, Dillard University, Tulane University to reopen academic } \\
\text { programs, the Southern Education Foundation, and Southwestern University for the development of } \\
\text { online course }\end{array}$ \\
\hline 5. Conrad N. Hilton Foundation & NV & $6,000,000$ & $\begin{array}{l}\text { To support the American Red Cross, the Baton Rouge Area Foundation, the Salvation Army, and the } \\
\text { Foundation for the Mid South }\end{array}$ \\
\hline $\begin{array}{l}\text { 6. H.N. and Frances C. Berger } \\
\text { Foundation }\end{array}$ & $\mathrm{CA}$ & $5,000,000$ & To support the Bush-Clinton Katrina Fund \\
\hline 7. Michael and Susan Dell Foundation & TX & $5,000,000$ & To support various relief and recovery organizations \\
\hline 8. Walton Family Foundation & AR & $4,000,000$ & To support the Salvation Army and various relief organizations \\
\hline 9. Robert Wood Johnson Foundation & NJ & $3,950,000$ & $\begin{array}{l}\text { To support the American Red Cross, the Salvation Army, Grantmakers in Aging, the National Association of } \\
\text { Community Health Centers, the National Association of County and City Health Officials, the Foundation for } \\
\text { the Mid South, the United Methodist Senior Services of Mississippi, the Agenda for Children, the National } \\
\text { Network of Public Health Institutes, and the Bayou La Batre Rural Health Clinic }\end{array}$ \\
\hline
\end{tabular}

10. Bill \& Melinda Gates Foundation

Top Ten Subtotal

All Other Independent Foundations
$3,000,000$

$\$ 93,950,629$

$\$ 23,785,500$

Source: The Foundation Center, Snapshot of Philanthropy's Response to the Gulf Coast Hurricanes, February 2006. Figures based on giving announced through November $18,2005$.

*Includes independent and family foundations; excludes company-sponsored foundations. 
Foundation and Corporate Gulf Coast Hurricane Response Funding by Donor State*

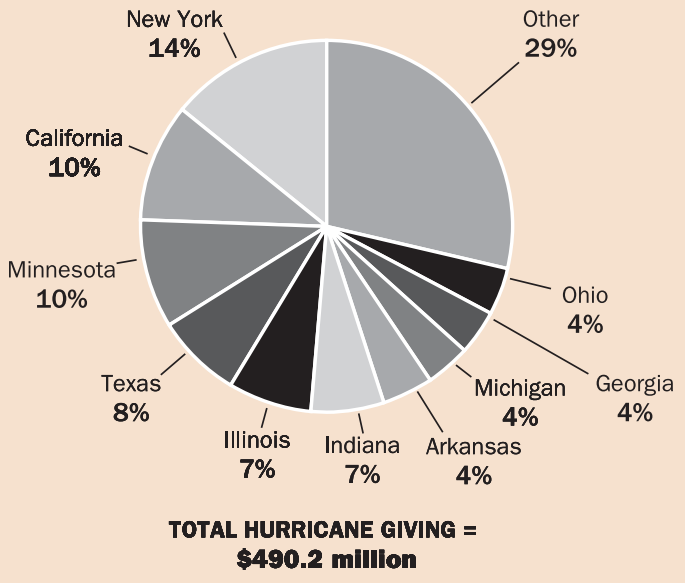

Source: The Foundation Center, Snapshot of Philanthropy's Response to the Gulf Coast Hurricanes, February 2006. Figures based on giving announced through November 18, 2005.

*Due to rounding, percentages do not total 100

Top Ten States by Total Foundation and Corporate Gulf Coast Hurricane Response Funding

\begin{tabular}{lrrrr} 
State & $\begin{array}{c}\text { No. of } \\
\text { Donors }^{\mathbf{1}}\end{array}$ & \multicolumn{1}{c}{$\%$} & \multicolumn{1}{c}{ Amount } & \multicolumn{1}{c}{$\%$} \\
\hline 1. New York & 49 & 13.5 & $\$ 70,130,000$ & 14.3 \\
2. California & 43 & 11.8 & $49,535,000$ & 10.1 \\
3. Minnesota & 14 & 3.9 & $46,534,000$ & 9.5 \\
4. Texas & 21 & 5.8 & $36,900,000$ & 7.5 \\
5. Illinois & 35 & 9.6 & $34,862,778$ & 7.1 \\
6. Indiana & 5 & 1.4 & $32,225,000$ & 6.6 \\
7. Arkansas & 2 & 0.6 & $21,000,000$ & 4.3 \\
8. Michigan & 14 & 3.9 & $19,685,000$ & 4.0 \\
9. Georgia & 10 & 2.8 & $19,610,000$ & 4.0 \\
10. Ohio & 26 & 7.2 & $19,316,907$ & 3.9 \\
$\quad$ Subtotal & $\mathbf{2 1 9}$ & $\mathbf{6 0 . 3}$ & $\mathbf{\$ 3 4 9 , 7 9 8 , 6 8 5}$ & $\mathbf{7 1 . 4}$ \\
$\quad$ All Other States & 144 & 39.7 & $\mathbf{\$ 1 4 0 , 3 9 1 , 8 5 9}$ & 28.6 \\
$\quad$ TOTAL & $\mathbf{3 6 3}$ & $\mathbf{1 0 0 . 0}$ & $\mathbf{\$ 4 9 0 , 1 9 0 , 5 4 4}$ & $\mathbf{1 0 0 . 0}$
\end{tabular}

- Corporate donors pledged $\$ 351.5$ million, or close to 72 percent of overall institutional giving made in response to Hurricane Katrina and the other 2005 Gulf Coast hurricanes. This figure includes cash donations and \$23.3 million in employee matching gifts. In fact, several major corporations eliminated their caps on corporate matching to increase the amount of support flowing to those affected by the hurricanes. (See "Corporate In-Kind Giving" for information on product and service donations made in response to the storms.)

100 independent, community, and other public foundations pledged \$138.7 million, or over 28 percent of institutional funding in response to the hurricanes. Independent foundations provided most of this support (\$117.7 million).

\section{Corporate In-Kind Giving}

Corporate and corporate foundation cash giving in response to the Gulf Coast hurricanes totaled $\$ 351.5$ million through mid-November 2005. Yet this figure reflected only part of their response to the disaster. The Foundation Center has tracked 101 corporations that provided an additional $\$ 195.7$ million $^{1}$ in in-kind commitments for immediate relief and recovery. Among in-kind contributions reported to date are Office Depot's $\$ 17$ million in supplies plus the contents of five stores; General Electric's \$10 million in medical devices, power generation equipment, and water purification equipment; Comcast's \$10 million and Cox Enterprises' \$8 million in free advertising space and time; and IBM's $\$ 3.2$ million in technology and services.

1. Figure based on value of products and services as reported by the corporations.

Source: The Foundation Center, Snapshot of Philanthropy's Response to the Gulf Coast Hurricanes, February 2006. Figures based on giving announced through November 18, 2005.

Top Ten Community and Other Public Foundations Ranked by Total Gulf Coast Hurricane Response Funding

\begin{tabular}{|c|c|c|c|c|}
\hline Donor Name & State & $\begin{array}{l}\text { Donor } \\
\text { Type }^{1}\end{array}$ & Amount & Purpose \\
\hline $\begin{array}{l}\text { 1. Lifeway Christian Resources of } \\
\text { the Southern Baptist Convention }\end{array}$ & $\mathrm{TN}$ & PC & $\$ 6,000,000$ & $\begin{array}{l}\text { To support various relief organizations, including the Baptist state conventions of Louisiana, } \\
\text { Mississippi, and Alabama }\end{array}$ \\
\hline 2. Baton Rouge Area Foundation & LA & $\mathrm{CM}$ & $3,794,560$ & For grants made through the foundation's Displaced Residents Fund \\
\hline $\begin{array}{l}\text { 3. Robert R. McCormick Tribune } \\
\text { Foundation }\end{array}$ & IL & $\mathrm{PC}$ & $1,000,000$ & For support of the McCormick Tribune Foundation Hurricane Katrina Relief Campaign \\
\hline 4. Missouri Foundation for Health & MO & $\mathrm{PC}$ & $1,000,000$ & $\begin{array}{l}\text { To assist Missouri health and mental health organizations in providing services to displaced Gulf Coast } \\
\text { residents }\end{array}$ \\
\hline 5. MusiCares Foundation & $\mathrm{CA}$ & PC & $1,000,000$ & To establish the MusiCares Hurricane Relief Fund to aid musicians affected by Hurricane Katrina \\
\hline 6. Pew Charitable Trusts & $\mathrm{PA}$ & $\mathrm{PC}$ & $1,000,000$ & To support the American Red Cross \\
\hline 7. Rapides Foundation & LA & $\mathrm{PC}$ & $1,000,000$ & $\begin{array}{l}\text { To support the United Way of Central Louisiana to provide assistance and shelter for victims and } \\
\text { families }\end{array}$ \\
\hline $\begin{array}{l}\text { 8. Muslim American Society } \\
\text { Freedom Foundation }\end{array}$ & $\mathrm{DC}$ & $\mathrm{PC}$ & $1,000,000$ & $\begin{array}{l}\text { To support the Healing Hands Coalition in feeding people in temporary shelter at the Houston } \\
\text { Astrodome }\end{array}$ \\
\hline 9. USA Funds & IN & PC & $1,000,000$ & To support the American Red Cross \\
\hline $\begin{array}{l}\text { 10. Columbus Foundation and } \\
\text { Affiliated Organizations }\end{array}$ & $\mathrm{OH}$ & $\mathrm{CM}$ & 594,657 & $\begin{array}{l}\text { To support the Hurricane Katrina Relief Fund of Columbus, the American Red Cross, and various relief } \\
\text { organizations }\end{array}$ \\
\hline Top Ten Subtotal & & & $\$ 17,389,217$ & \\
\hline All Others & & & $\$ 3,607,250$ & \\
\hline
\end{tabular}

Source: The Foundation Center, Snapshot of Philanthropy's Response to the Gulf Coast Hurricanes, February 2006. Figures based on giving announced through November $18,2005$. ${ }^{1} \mathrm{CM}=$ Community Foundation; $\mathrm{PC}=$ Public Charity/Other. 
- Corporations, foundations, and other institutional donors across the country have made pledges to support relief, recovery, and building in the aftermath of the Gulf Coast hurricanes. New York and California-based corporations and foundations provided close to one-quarter of the support reported through mid-November 2005. Other states accounting for at least 5 percent of support included Minnesota, Texas, Illinois, and Indiana.

\section{THE RECIPIENTS OF SUPPORT}

The following is a brief analysis of commitments from institutional donors to approximately 115 recipient groups, including relief funds created by relief agencies, corporations, and foundations; emergency relief and other service providers; local nonprofits directly affected by the disaster; and organizations working on issues related to the disaster.

- The American Red Cross (ARC) ranked as by far the largest named recipient of contributions from foundation and corporate donors in response to hurricanes Katrina and Rita. ARC received $\$ 156.3$ million, or 31.9 percent of designated support. By mid-December, ARC had raised $\$ 1.85$ billion from individual and institutional donors in response to the 2005 Gulf Coast hurricanes. ARC estimates that the cost of its relief efforts will top $\$ 2$ billion, with the vast majority of this support (74.3 percent) providing emergency financial assistance to hurricane victims, followed by smaller shares for purposes such as food and shelter (16.3 percent), additional Red Cross support (4.5 percent)-e.g., reconnecting families separated by the hurricanes-and physical and mental health services (0.4 percent). ${ }^{4}$

- Nine out of the top 15 recipients of institutional donors will either exclusively or primarily support hurricane relief and recovery through regranting of the dollars they have raised to affected individuals or to other organizations. Intermediaries range from funders based in the affected region (Baton Rouge Area Foundation, Foundation for the Mid South), to existing national entities (ARC, Salvation Army, United Way of America), to relief funds created by corporations (Starkey Help America Hear Project, Friedkin Disaster Relief Fund), to entities created in direct response to the disaster (Bush-Clinton Katrina Fund).

- Close to 38 percent of institutional giving (\$185 million) could not be assigned to a recipient because donors either had not yet designated a recipient (\$170.6 million, or 34.9 percent) or broken down amounts pledged to various named recipients (\$14.4 million, or 2.9 percent)

\section{Endnotes}

1. By comparison, foundation and corporate $9 / 11$ response funding totaled $\$ 1.1$ billion as of December 2004

2. Estimate of total private Gulf Coast hurricanes response funding released by the Center on Philanthropy at Indiana University on December 13, 2005.

3. See Giving USA Foundation, Giving USA 2005: The Annual Report on Philanthropy for the Year 2004, ed. by M. Brown, Indianapolis, IN: Giving USA Foundation, 2005

4. See American Red Cross, "Turning Compassion into Action-Dollars at Work: Hurricanes Katrina, Rita, and Wilma," www.redcross.org/news/ds/hurricanes/katrina_facts.html, Internet accessed on January 3, 2006.
Foundation and Corporate Gulf Coast Hurricane Response Funding by Type of Recipient*

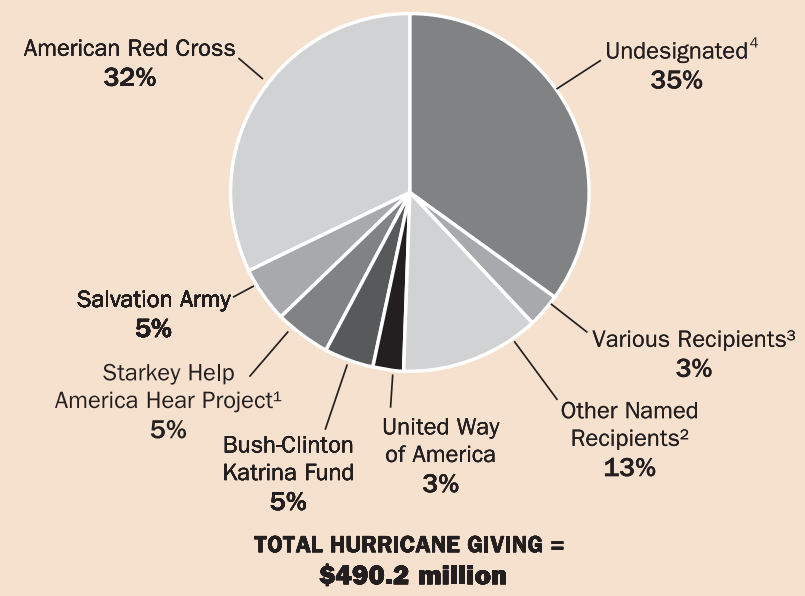

Source: The Foundation Center, Snapshot of Philanthropy's Response to the Gulf Coast Hurricanes, February 2006. Figures based on giving announced through November 18, 2005.

*Due to rounding, percentages may not total 100 . Shows individual organizations that received more than 2 percent of funding.

The Help America Hear Project is a business recovery program designed to help with employment, new business plans, and office relocation for hurricane victims.

${ }^{2}$ Named recipients accounting for less than 2 percent of grant dollars.

${ }^{3}$ Various recipients named but amount not reported by recipient.

${ }^{4}$ No recipient named at time of pledge.

Top 15 Designated Recipients of Foundation and Corporate Gulf Coast Hurricane Response Funding

\begin{tabular}{|c|c|c|c|}
\hline Recipient/Recipient Fund & State & Amount $^{1}$ & $\begin{array}{l}\% \text { of Total } \\
\text { Funding }\end{array}$ \\
\hline 1. American Red Cross $^{2}$ & DC & $\$ 156,253,195$ & 32.1 \\
\hline 2. Salvation Army & VA & $25,032,000$ & 5.1 \\
\hline $\begin{array}{l}\text { 3. Starkey Help America Hear } \\
\text { Project }^{3}\end{array}$ & $\mathrm{MN}$ & $25,000,000$ & 5.1 \\
\hline 4. Bush-Clinton Katrina Fund & NY & $22,095,000$ & 4.5 \\
\hline 5. United Way of America & VA & $12,650,000$ & 2.6 \\
\hline 6. Habitat for Humanity & GA & $7,851,000$ & 1.6 \\
\hline $\begin{array}{l}\text { 7. Hurricane Funds of the Baton } \\
\text { Rouge Area Foundation }{ }^{4}\end{array}$ & LA & $4,522,000$ & 0.9 \\
\hline 8. CDC Foundation & GA & $3,000,000$ & 0.6 \\
\hline 9. Southern Education Foundation & GA & $2,800,000$ & 0.6 \\
\hline $\begin{array}{l}\text { 10. HomeAid America Gulf Coast } \\
\text { Rebuilding Fund }\end{array}$ & $\mathrm{CA}$ & $2,500,000$ & 0.5 \\
\hline 11. America's Second Harvest & IL & $2,354,000$ & 0.5 \\
\hline 12. Foundation for the Mid South & MS & $2,300,000$ & 0.5 \\
\hline 13. Friedkin Disaster Relief Fund ${ }^{5}$ & TX & $2,000,000$ & 0.4 \\
\hline 14. Xavier University of Louisiana & LA & $1,200,000$ & 0.2 \\
\hline 15. Florida Hurricane Relief Fund & $\mathrm{FL}$ & $1,050,000$ & 0.2 \\
\hline
\end{tabular}

Source: The Foundation Center, Snapshot of Philanthropy's Response to the Gulf Coast Hurricanes, February 2006. Figures based on giving announced through November 18, 2005.

${ }^{1}$ Excludes undesignated pledges and unspecified amounts donated to named recipients.

${ }^{2}$ Includes only giving to the national American Red Cross.

${ }^{3}$ The Help America Hear Project is a business recovery program designed to help with employment, new business plans, and office relocation for hurricane victims.

${ }^{4}$ The Baton Rouge Area Foundation is also represented as a donor. As of mid-November 2005, the foundation's Displaced Residents Fund had received contributions totaling $\$ 14.2$ million. Of this total, it had already provided $\$ 3.8$ million in grants. The foundation has also established a Hurricane Katrina New Orleans Recovery Fund. ${ }^{5}$ The Friedkin Disaster Relief Fund was established by the Friedkin Companies, owner of Gulf States Toyota, to provide immediate and long-term aid to Toyota and dealership employees and their families in the Gulf States region. 